Check for updates

Cite this: RSC Adv., 2018, 8, 21472

\title{
The self-assembly of monosubstituted BODIPY and HFBI-RGD $\uparrow$
}

\author{
Fengnan Sun, ${ }^{a}$ Guang Yang, ${ }^{\text {ab }}$ Qian Zhang, ${ }^{\text {a }}$ Zhongbo Xue, ${ }^{a}$ Chengzhi Gu, ${ }^{c}$ \\ Zhuozhi Chen, ${ }^{d}$ Boying Yan, ${ }^{\text {e Yaqing Feng, }}$, ${ }^{\text {ab }}$ Zefang Wang ${ }^{* d}$ and Shuxian Meng (DD *a

\begin{abstract}
A novel fluorescent probe was constructed by the self-assembly of monosubstituted BODIPY and a novel targeted hydrophobin named hereafter as HFBI-RGD. Optical measurements and theoretical calculations confirmed that the spectral properties of the probe were greatly influenced by the BODIPY structure, the appropriate volume of BODIPY and the cavity of HFBI-RGD. The experiments in vivo and ex vivo demonstrated that the probe had excellent ability for tumor labelling.
\end{abstract}

Received 29th April 2018

Accepted 25th May 2018

DOI: $10.1039 / \mathrm{c} 8 \mathrm{ra03687j}$

rsc.li/rsc-advances

\section{Introduction}

Functional dyes have been applied to a variety of research fields such as fluorescent molecular probes, ${ }^{\mathbf{1 , 2}}$ dye sensitized solar cells (DSSCs) ${ }^{3,4}$ and photodynamic therapy (PDT). ${ }^{5,6}$ As an indispensable tool for modern biomedical research and preclinical study, fluorescence imaging has attracted much attention. Dyes emitting in the far-red or near infra-red (NIR) region (650-900 nm) are ideal materials for this application. ${ }^{7}$ Of all these dyes, 4,4-difluoro-4-bora-3a,4a-diaza-s-indacenes (BODIPYs) are promising for their high quantum yields, large extinction coefficients, and good absorption and emission intensities. However, critical defects including short wavelength (470-530 nm), ${ }^{8}$ low water solubility and poor biocompatibility are yet to be solved for further applications. Many strategies are used to modify the BODIPY core to tune the emission into red/ near infrared region by mainly including a conjugate structure at the 3,5-position, ${ }^{9,10}$ replacing the meso-carbon atom of the BODIPY framework to form aza-BODIPY, ${ }^{\mathbf{1 1}, 12}$ and displacing the fluoride atom in conventional BODIPY with oxygen (carbon) atom to form O-BODIPY (C-BODIPY). ${ }^{\mathbf{1 3 - 1 5}}$ Hydrophobicity can be modified by introducing an ionized hydrophilic ${ }^{\mathbf{1 6}, \mathbf{1 7}}$ or neutral hydrophilic group ${ }^{\mathbf{1 8 , 1 9}}$ and self-assembly of amphiphilic block copolymer. $^{20}$

${ }^{a}$ School of Chemical Engineering and Technology, Tianjin University, Tianjin 300050, China.E-mail: msxmail@tju.edu.cn

${ }^{b}$ Collaborative Innovation Center of Chemical Science and Engineering, Tianjin 300072, China

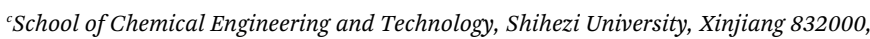
China

${ }^{d}$ School of Life Sciences, Tianjin University, Tianjin 300072, China. E-mail: zefangwang@tju.edu.cn

${ }^{e}$ General Hospital of Tianjin Medical University, Tianjin 300052, China

$\dagger$ Electronic supplementary information (ESI) available: Experimental procedures, ${ }^{1} \mathrm{H}$ NMR, SEM, UV/vis, fluorescence spectrum, computational data of BODIPYs, cytotoxicity, confocal fluorescence images, in vivo experiment. See DOI: $10.1039 / \mathrm{c} 8 \mathrm{ra} 03687 \mathrm{j}$
The hydrophobins are small $(7-15 \mathrm{kDa})$ proteins produced by the filamentous fungi during a specific period. Their structures have been discussed in detail previously, ${ }^{21-25}$ and Fig. $1^{20}$ shows the three-dimensional structure of one hydrophobin. The hydrophobins possess amphiphilic characteristics, remarkable surface activity ${ }^{26,27}$ and various biological functions, which makes them fascinating materials across a number of fields. Integrin $\alpha_{v} \beta_{3}$ (ref. 28) can serve as a receptor for a variety of extracellular matrix proteins displaying the RGD tripeptide sequence. ${ }^{29}$ Due to high expression in endothelial cells during tumor angiogenesis, $\alpha_{v} \beta_{3}$ is considered as a suitable membrane structure for tumor targeting. ${ }^{30,31}$ In this study, a hydrophobin modified by RGD peptide was prepared by genetic engineering. Considering the specific binding of RGD and $\alpha_{\mathrm{v}} \beta_{3}$, we envisaged that this hydrophobin named hereafter as HFBI-RGD can be used as a useful tool for labelling tumors.

We designed three monosubstituted BODIPYs (Scheme 1) and prepared HFBI-RGD. Then, the dyes were wrapped into the cavity formed by the self-assembly of HFBI-RGD to produce protein nanocage-fluorescent probes, which not only retained the fluorescence emission of BODIPYs, but also displayed water solubility, biocompatibility and tumor-targeting. We further analysed the main factors which affected the spectral properties

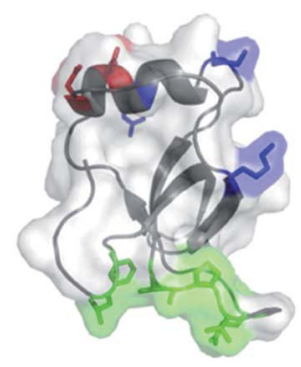

Fig. 1 Three-dimensional structure of HFBI. The green part on the surface of HFBI is the hydrophobic patch that can bind to the hydrophobic solid surface. 

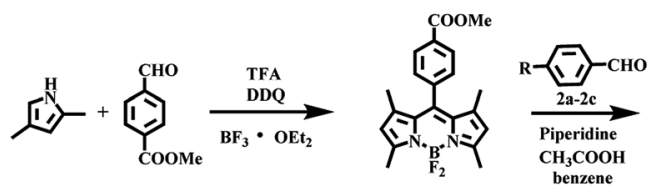
benzene

$\mathbf{R}=$

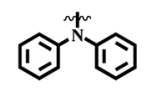

a

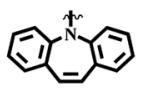

b

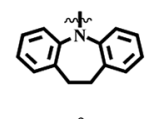

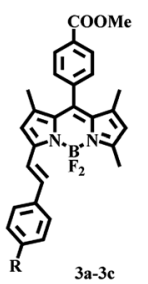

Scheme 1 Synthesis of three mono-substituted BODIPYs.

of these protein nanocage-fluorescent probes. Optical measurements and theoretical calculations confirmed that the spectral properties were greatly influenced by the BODIPY structure, the appropriate volume of BODIPY and the cavity of HFBI-RGD. Last, using live animal imaging experiments, the probes were verified to have the excellent capability of targeting tumors.

\section{Results and discussion}

\subsection{Synthesis and optical characterization of $3 a-3 c$}

Our initial efforts involved the synthesis and optical measurement of BODIPYs. In this study, we reported three new asymmetric structures with flexible and semi-rigid triarylamino groups at the 3-position of the framework (Scheme 1). The dyes were characterized by ${ }^{1} \mathrm{H}$ NMR, ${ }^{13} \mathrm{C}$ NMR and HRMS. The optical results demonstrated that the mono-substituted structures possessed good spectral properties, especially with the fluorescence emission in the visible region. 3a-3c were found to show similar profiles with the maximum absorption wavelength $\left(\lambda_{\max }\right)$ of approximately $600 \mathrm{~nm}$ and an intense emission peak at around $650 \mathrm{~nm}$ (Fig. 2 and S2 in ESI $\dagger$ ). In consistent with their fluorescence quantum yields $\left(\Phi_{3 \mathbf{a}}=0.38\right.$, $\Phi_{3 \mathbf{b}}=0.73$, and $\left.\Phi_{3 \mathbf{c}}=0.46\right)$, which might be ascribed to the triarylamino groups at the C3 position. The dye 3a had the lowest fluorescence intensity, which was caused by the free rotation of benzene rings in the triarylated amine group. ${ }^{32,33}$

The dyes $\mathbf{3 b}$ and $\mathbf{3} \mathbf{c}$ with rigid triarylamino groups exhibited higher emission peaks, especially compound $\mathbf{3 b}$. The absorption and emission spectral behaviors of the dyes in other solvents are also presented (Fig. S3 in ESI†). As indicated by the plots, the fluorescence intensity decreased with the increase in polarity, which could be due to a positive solvent kinetic effect. $^{34,35}$

Because of the presence of $\pi-\pi$ interactions between molecules, the reduced HOMO-LUMO energy gap resulted in a slight bathochromic shift. ${ }^{36,37}$ Thus, a slight red-shift appeared for all these dyes with the increase in concentration. Among the three BODIPY dyes, dye $\mathbf{3 b}$ exhibited the best co-planarity; on the one hand, this property limited free rotation, resulting in the least non-radiative energy loss but on the (a)

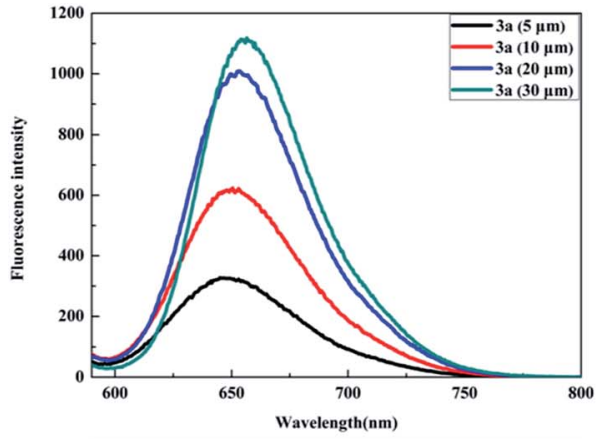

(b)

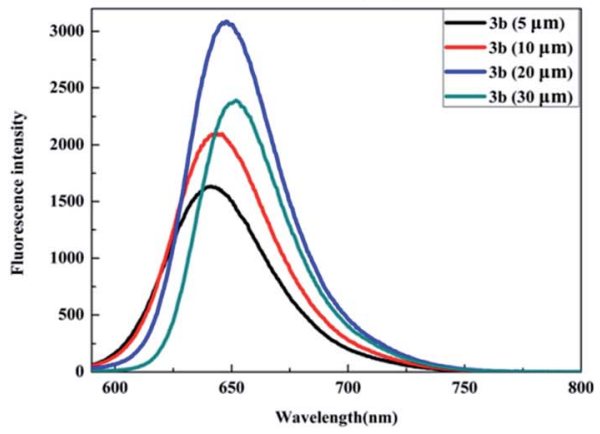

(c)

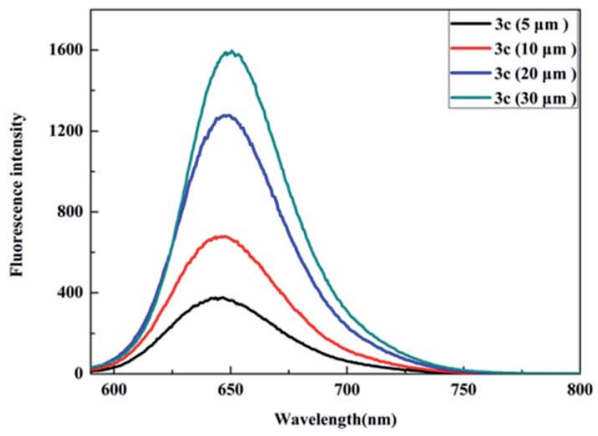

Fig. 2 Fluorescence spectra of dyes $3 a, 3 b$ and $3 c$ in $\mathrm{CH}_{2} \mathrm{Cl}_{2}$ with different concentrations. Condition: excitation wavelength $560 \mathrm{~nm}$.

other hand, it greatly contributed to intermolecular $\pi-\pi$ aggregation compared to the observations for dye $\mathbf{3 a}$ and dye 3c. Dye $\mathbf{3 b}$ showed the strongest emission and exhibited a sharp drop in fluorescence intensity at high concentration.

\subsection{The morphology of BODIPY and HFBI-RGD/BODIPY}

We utilized scanning electron microscopy to characterize the morphological changes between BODIPY and HFBI-RGD/ BODIPY. The SEM images suggested that the morphological variation was strongly and closely related to HFBI-RGD. The rightmost image of Fig. 3b shows the membrane structure of the hydrophobic protein modified by RGD. In the self-assembly process, the amphiphilic film entrapped the BODIPY molecule to form an analogous structure to that of a microcapsule, varying the holistic morphology and dispersity of BODIPY. As depicted in Fig. 3c, HFBI-RGD/BODIPY categorically showed much smaller size and regular shape in comparison to BODIPY dyes, which presented massive texture, as shown in Fig. 3a. 
(a)

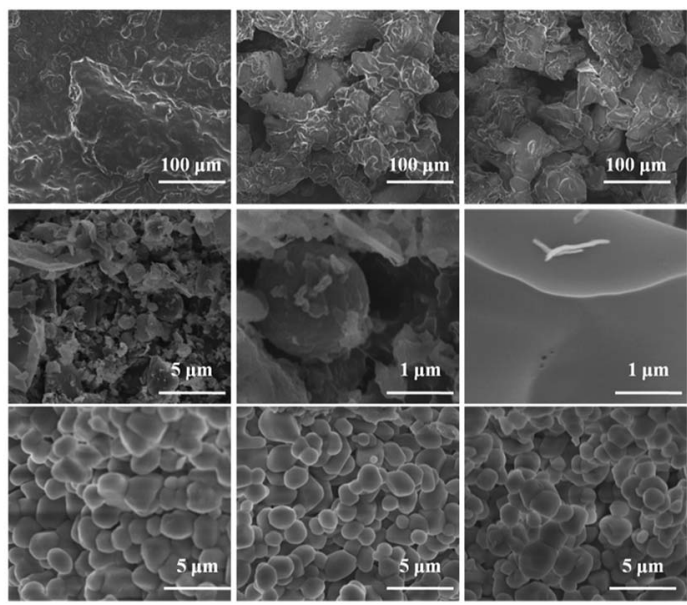

Fig. 3 SEM images of BODIPY, HFBI-RGD and HFBI-RGD/BODIPY. (a) $B O D I P Y$. The images from the left to right indicate the shapes of dyes $3 a-3 c$, respectively. (b) HFBI-RGD. The figures from the left to right exhibit the overall, single, membrane of hydrophobic protein modified by RGD. (c) HFBI-RGD/BODIPY. The images from the left to right indicate the shapes of $\mathrm{HFBI}-\mathrm{RGD} / 3 \mathrm{a}-3 \mathrm{c}$, respectively.

\subsection{Fluorescence properties of the HFBI-RGD/BODIPY fluorescent probe}

To overcome the hydrophobicity of BODIPY dyes, we encapsulated the dyes with the targeted hydrophobin HFBI-RGD by selfassembly to form a protein nanocage, which exhibited water solubility and excellent spectroscopic properties (Fig. 4), and the protein nanocage also showed stability without aggregation caused by the volatilization of dichloromethane (inset in Fig. 4b). As the figure depicts, the fluorescence intensity increased with the HFBI-RGD concentration in a non-linear manner. The corresponding plot (Fig. S4 in ESI $\dagger$ ) clearly indicates the relationship between fluorescence and HFBI-RGD. When the concentration of HFBI-RGD reached a critical value, a decline in the fluorescence intensity was observed. The following presumption might account for this phenomenon: At low concentrations, the hydrophobin molecules in the solution were insufficient to disperse the dyes, whereas the scattered dyes were linked by the aggregation of redundant hydrophobins at high concentrations. ${ }^{20}$ Another factor that was taken into consideration was the cavity in the structure of hydrophobins. Limited by the size of the cavity, fluorescence intensity for HFBIRGD/BODIPY was not observed when the BODIPY dyes were mixed in the organic solvents. When the concentration of HFBIRGD was low, an excess of dye caused aggregation, resulting in the decrease of fluorescence intensity and vice versa. We also found that the critical value of dye $3 \mathrm{a}$ was $0.15 \mathrm{mg} \mathrm{mL}^{-1}$, whereas that of each of the other dye was $0.20 \mathrm{mg} \mathrm{mL}^{-1}$, and this divergence was observed due to the different substituents at the 3-position of the central structure. The fluorescence emission wavelengths of the three dyes blue-shifted slightly in close proximity to $645 \mathrm{~nm}$ compared to those of the dyes in dichloromethane, which might be caused by the negative solvatochromic effect. ${ }^{38}$

In the process of encapsulating the dyes with HFBI-RGD, we also noticed another interesting phenomenon. The compound (a)

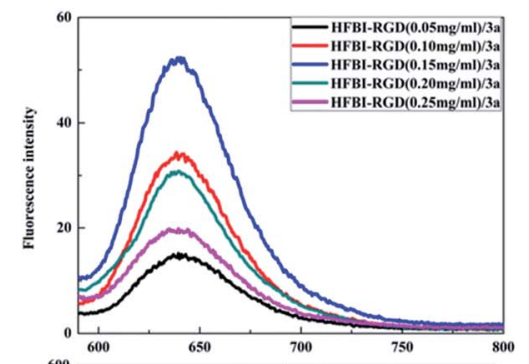

(b)

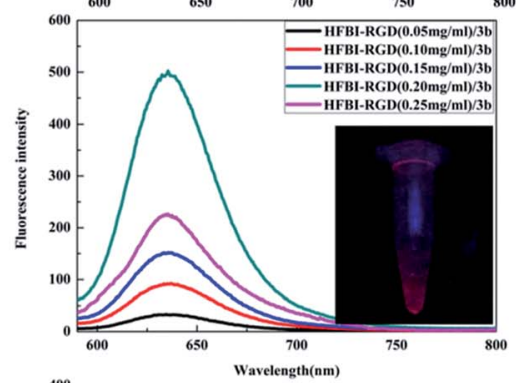

(c)

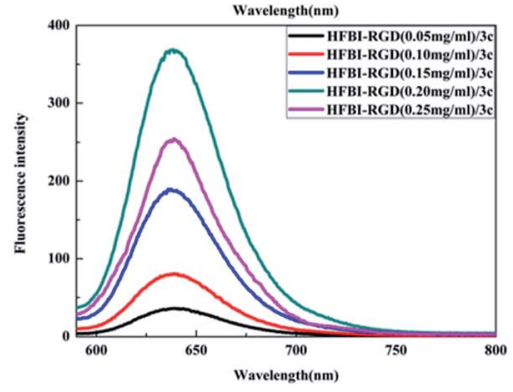

Fig. 4 Fluorescence spectra of dyes in the presence of different concentrations of HFBI-RGD aqueous solutions. (a) HFBI-RGD/3a. (b) $\mathrm{HFBI}-\mathrm{RGD} / 3 \mathrm{~b}$. Inset: the image of $\mathrm{HFBI}-\mathrm{RGD} / 3 \mathrm{~b}$ upon the irradiation of ultraviolet lamp (365 nm) after two weeks. (c) HFBI-RGD/3c.

1 and monosubstituted BODIPY molecules 3a-3c could be wrapped by hydrophobins to form protein nanocages with strong fluorescence emissions (Fig. S6 in ESI, $\uparrow$ 4), but disubstituted BODIPY molecules could not be wrapped by the hydrophobins. Different concentrations of dyes and hydrophobins were assayed in this self-assembly process, but no fluorescence emission of the disubstituted BODIPYs was observed. We attributed this fluorescence quenching to the difference in volumes of the BODIPYs. The volumes of these dyes are listed in Table S1. $\dagger$ On account of the influence of other substituents, namely, triarylamino groups at the 5-position and steric hindrance, the disubstituted dyes indisputably had bigger volumes than compound 1 and monosubstituted dyes. Based on these evidences, we speculated that hydrophobins with a certain vacuum structure could be prepared by means of ultrasonic agitation. This cavity might affect the fluorescence properties of the dyes of different sizes, which were wrapped into the protein nanocages.

\subsection{Biological properties}

Finally, we examined HFBI-RGD/BODIPY as a fluorescent probe for targeting the tumor tissue. First, the cytotoxicity of the HFBI-RGD/BODIPY fluorescent probe to glioma cells was studied. The glioma cells were incubated with HFBI-RGD/ 


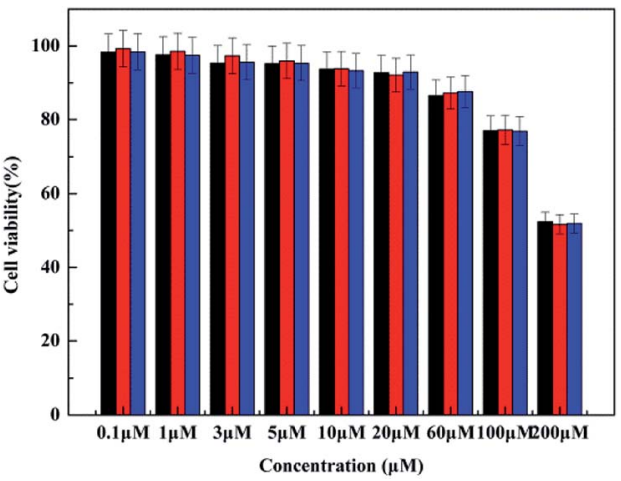

Fig. 5 Cytotoxicity of HFBI-RGD/BODIPY fluorescent probe by MTT assay. Black, cytotoxicity of HFBI-RGD/3a; red, cytotoxicity of HFBI$\mathrm{RGD} / 3 \mathrm{~b}$; blue, cytotoxicity of HFBI-RGD/3c. $(n=3, * p<0.05)$.

BODIPY at different concentration gradients $(0 \mu \mathrm{M}, 0.1 \mu \mathrm{M}, 1$ $\mu \mathrm{M}, 3 \mu \mathrm{M}, 5 \mu \mathrm{M}, 10 \mu \mathrm{M}, 20 \mu \mathrm{M}, 60 \mu \mathrm{M}, 100 \mu \mathrm{M}$, and $200 \mu \mathrm{M})$ for $48 \mathrm{~h}$. The data showed cell survival of approximately 80 percent at $100 \mu \mathrm{M}$ and 56 percent at $200 \mu \mathrm{M}$. The probes exhibited weak even negligible cytotoxicity to the U-87 cells at low concentration (Fig. 5) and thus, we used a low concentration $(5 \mu \mathrm{M})$ in the follow-up experiment.

Next, we tested the capability of tumor-targeting by confocal fluorescence microscopy. U-87 cells treated with probes displayed red fluorescence under a confocal fluorescence microscope (Fig. 6). A bright red fluorescence emission was observed clearly when the cells were treated with HFBI$\mathrm{RGD} / \mathbf{3 b}$. By contrast, the cells incubated with HFBI-RGD/3a and HFBI-RGD/3c showed indistinct red fluorescence emissions. These changes were consistent with the previous optical data wherein HFBI-RGD/3b displayed better fluorescence intensity than $\mathbf{3 a}$ and $\mathbf{3 c}$. It was worth noting that when the cells were treated with $\mathrm{HFBI}-\mathrm{RGD} /(\mathbf{3 a} \mathbf{3}-\mathbf{3 c})$, more probes could enter into the cells, which was concluded from the area under the curves of fluorescence spectra in the graphs. The results indicated that HFBI-RGD/BODIPY possessed the ability of targeting the cancer cells to some extent.

Nude mice bearing U-87-derived glioma were injected with HFBI-RGD/3b or HFBI/3b fluorescent probes $(5 \mu \mathrm{M})$ via the tail vein. As shown in the real time-dependent fluorescence images of the living tumor-bearing nude mice (Fig. 7a), fuzzy fluorescence at the tumor site was observed at wavelengths close to $645 \mathrm{~nm}$, which may not be completely devoid of interference from the normal tissues. The tumor tissues could be distinguished from the surrounding normal tissues with a certain degree of clarity. Weak fluorescence was observed at the tumor site after $2 \mathrm{~h}$. But as time elapsed, more fluorescent probes gathered around the tumor tissues, and this was accompanied with higher fluorescence intensity, which reached a peak after $24 \mathrm{~h}$. Negligible fluorescence emission was observed after $72 \mathrm{~h}$ because of the rapid clearance of the fluorescence probe. To further characterize the tumor-targeting property of the probe, tumor tissues and main organs were harvested at certain times post labelling. The tumors exhibited persistent and strong fluorescence (a)
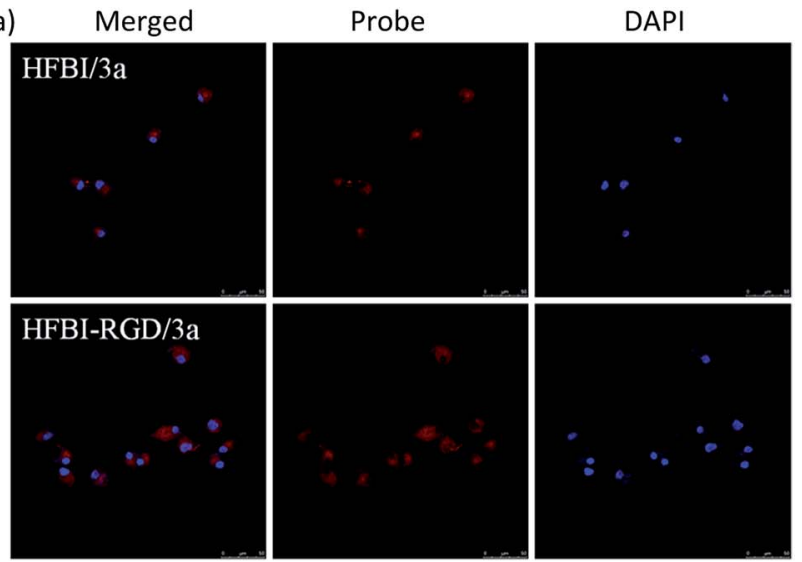

(b)
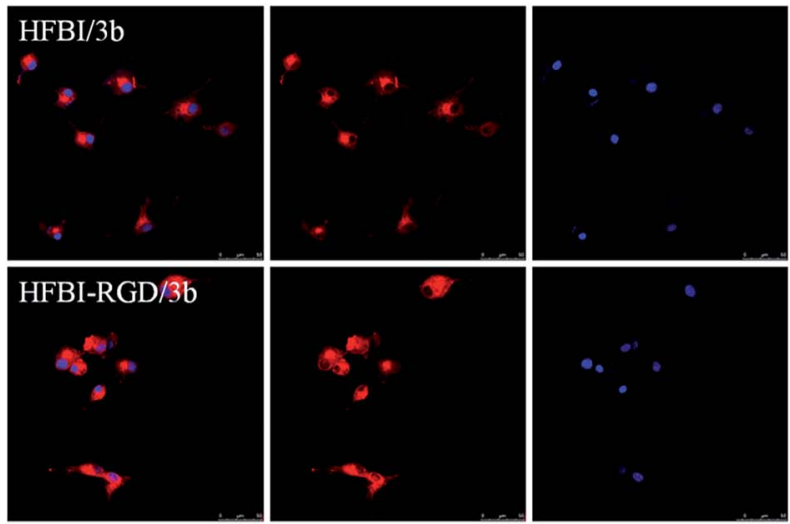

(c)
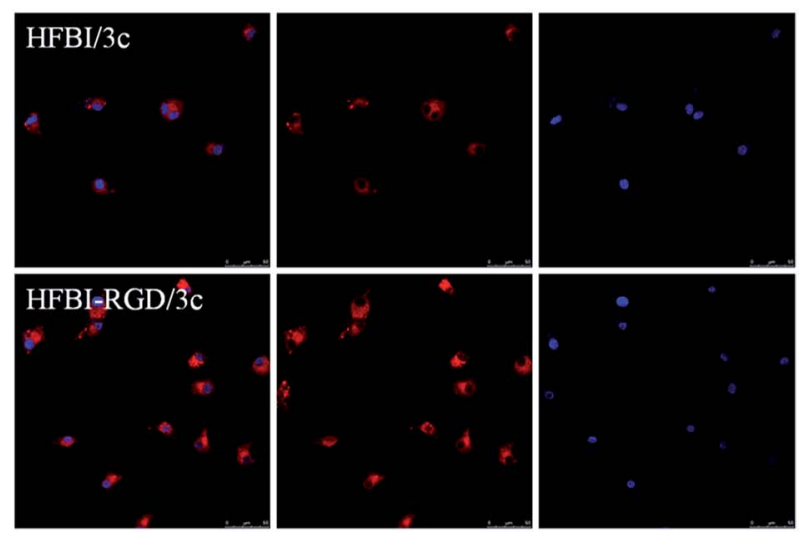

Fig. 6 Confocal fluorescence images $(40 \times)$ of glioma cells U-87 incubated with $\mathrm{HFBI} / 3 \mathrm{a}$ or $\mathrm{HFBI}-\mathrm{RGD} / 3 \mathrm{a}, \mathrm{HFBI} / 3 \mathrm{~b}$ or $\mathrm{HFBI}-\mathrm{RGD} / 3 \mathrm{~b}$, $\mathrm{HFBI} / 3 \mathrm{c}$ or $\mathrm{HFBI}-\mathrm{RGD} / 3 \mathrm{c}(5 \mu \mathrm{M})$ for $4 \mathrm{~h}$ at $37^{\circ} \mathrm{C}$. Merged images, probe (red), cell nuclei (blue) are shown. (a) $U-87$ cells were incubated with $\mathrm{HFBI} / 3 \mathrm{a}$ or $\mathrm{HFBI}-\mathrm{RGD} / 3 \mathrm{a}(5 \mu \mathrm{M})$ for $4 \mathrm{~h}$; (b) $\mathrm{U}-87$ cells were incubated with $\mathrm{HFBI} / 3 \mathrm{~b}$ or $\mathrm{HFBI}-\mathrm{RGD} / 3 \mathrm{~b}(5 \mu \mathrm{M})$ for $4 \mathrm{~h}$; (c) U-87 cells were incubated with $\mathrm{HFBI} / 3 \mathrm{c}$ or $\mathrm{HFBI}-\mathrm{RGD} / 3 \mathrm{c}(5 \mu \mathrm{M})$ for $4 \mathrm{~h}$. The excitation wavelengths of DAPI and HFBI-RGD/BODIPY fluorescent probe were $405 \mathrm{~nm}$ and $560 \mathrm{~nm}$, respectively.

emission without the interference of autofluorescence from the background (Fig. 7b). The results of the control experiment showed that no fluorescence was observed in the tumor 
(a)

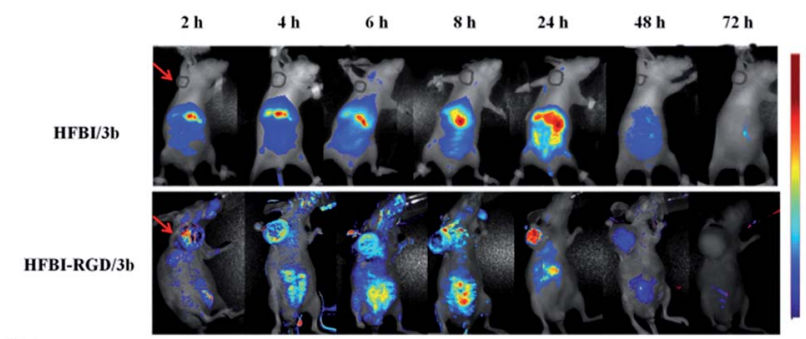

(b)

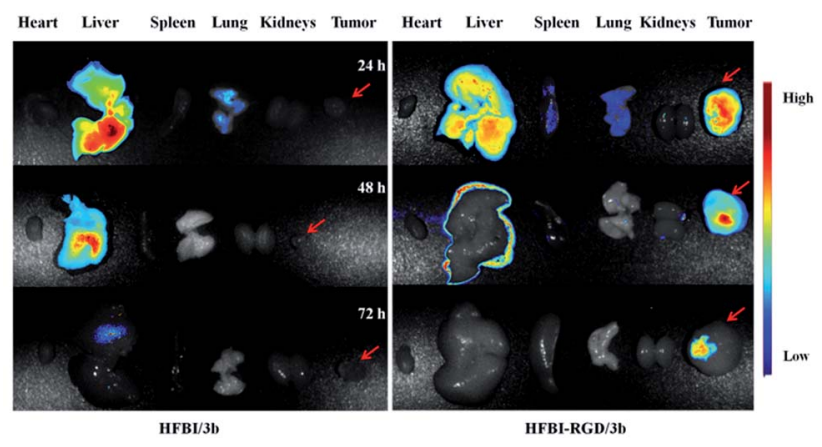

Fig. 7 (a) Time-dependent in vivo fluorescence images of nude mice bearing glioma cells $\mathrm{U}-87$ after tail intravenous injection. Images were taken at 2 h, 4 h, 6 h, 8 h, 24 h, 48 h, and 72 h. (b) Fluorescence images of the main organs (heart, liver, spleen, lung, and kidneys) and tumors from $\mathrm{U}-87$ tumor-bearing mice at different time intervals ( $24 \mathrm{~h}, 48 \mathrm{~h}$, and $72 \mathrm{~h}$ ).

tissue whether in the real time-dependent fluorescence images or anatomic images (Fig. 7). These results confirmed the capability of HFBI-RGD/BODIPY fluorescent probes to target the tumors.

\section{Conclusions}

In summary, we have shown the construction of a novel fluorescent probe-HFBI-RGD/BODIPY. Three new asymmetric structures with flexible and semi-rigid triarylamino groups at the 3-position of the framework were designed and synthesized. A novel hydrophobin modified by peptides RGD was prepared by genetic engineering. Next, HFBI-RGD was exploited to encapsulate the dyes to form protein nanocages by selfassembly. The protein nanocages not only retained the fluorescence emission of BODIPYs, but also showed water solubility, biocompatibility and tumor-specific targeting. Subsequently, we turned our attention to the main factors which affected the spectral properties of the protein nanocages. Optical measurements and theoretical calculations confirmed that the spectral properties were greatly influenced by the BODIPY structure, the appropriate volume of BODIPY and the cavity of HFBI-RGD. The experiments in vivo and ex vivo ascertained that the fluorescent probe had a powerful tumortargeting property.

\section{Experimental section}

\subsection{Materials and instruments}

All solvents and starting materials were commercially available and used without further purification (unless specified). The synthetic routes of $\mathbf{2 b}$ and $\mathbf{2 c}$ were described in our lab's previous publications..$^{39}$ HFBI-RGD was purified by our laboratory. ${ }^{1} \mathrm{H}$ NMR and ${ }^{13} \mathrm{C}$ NMR spectra were recorded on a Bruker AV400 MHz spectrometer. HRMS results were obtained with a Bruker microTof-QII instrument. Absorption spectra were measured using Shimadzu UV-1800. Fluorescence spectra were determined on a Hitachi F-2500 spectrophotometer. The morphology was obtained with a scanning electron microscope (S-4800, Hitachi, Japan). The cell viability was analysed using a microplate reader (Perkin Elmer Enspire). Fluorescent images of cells were obtained with a confocal microscope (Ultra VIEM Vox, PerkinElmer). In vivo images were captured with a Cri Maestro In vivo imaging system (Cri, Woburn, MA).

\subsection{Synthesis}

Synthesis of compound 1. Methyl 4-formylbenzoate (0.864 g, $5.2 \mathrm{mmol}$ ) was dissolved in $32 \mathrm{~mL} \mathrm{CH}_{2} \mathrm{Cl}_{2}$ in a $100 \mathrm{~mL}$ round-bottom flask equipped with a magnetic stirrer and then, 2,4-dimethylpyrrole $(1 \mathrm{~mL}, 10.0 \mathrm{mmol})$ was added. The mixture was stirred in the dark for $30 \mathrm{~min}$ with nitrogen bubbling to remove dissolved oxygen, followed by addition of $0.08 \mathrm{~mL}$ trifluoroacetic acid with syringe slowly under nitrogen atmosphere to continue the reaction. After $4 \mathrm{~h}$, the particles of the raw material 2,4-dimethylpyrrole disappeared (monitored by TLC), after which the nitrogen atmosphere was removed. DDQ (2,3-dichloro-5,6-dicyano1,4-benzoquinone) (1.2 g, $2.6 \mathrm{mmol})$ dissolved in a mixed solution ( $5 \mathrm{~mL} \mathrm{CH}_{2} \mathrm{Cl}_{2}$ and $\left.5 \mathrm{~mL} \mathrm{THF}\right)$ was introduced with constant-voltage funnels. The mixture was stirred in the absence of light for $1 \mathrm{~h}$ at room temperature and then, $8.6 \mathrm{~mL}$ triethylamine was added drop by drop. Subsequently, $8.6 \mathrm{~mL}$ boron trifluoride etherate was added in the same way under the condition of an ice bath. The ice bath was removed after $30 \mathrm{~min}$, and the reaction mixture was stirred in the dark overnight. The product of the reaction was washed with water and extracted with dichloromethane. The extracted liquid was dried over anhydrous sodium sulfate. Dichloromethane was removed by evaporation to obtain the crude product,which was further purified by column chromatography (silica gel) using $\mathrm{CH}_{2} \mathrm{Cl}_{2} /$ hexane $=2 / 1$ as eluent to yield a red solid (287 mg, yield 14.4\%). ${ }^{1} \mathrm{H}$ NMR (400 MHz, $\left.\mathrm{CDCl}_{3}, \delta\right): 8.18(\mathrm{~d}, J$ $=8.0 \mathrm{~Hz}, 2 \mathrm{H}, \mathrm{Ph}-\mathrm{H}) ; 7.41(\mathrm{~d}, J=8.0 \mathrm{~Hz}, 2 \mathrm{H}, \mathrm{Ph}-\mathrm{H}) ; 5.99(\mathrm{~s}$, $2 \mathrm{H}$, pyrrole- $\mathrm{H}) ; 3.97\left(\mathrm{~s}, 3 \mathrm{H},-\mathrm{COOCH}_{3}\right) ; 2.56(\mathrm{~s}, 6 \mathrm{H}$, pyrrole$\left.\mathrm{CH}_{3}\right) ; 1.36\left(\mathrm{~s}, 6 \mathrm{H}\right.$, pyrrole- $\left.\mathrm{CH}_{3}\right) .{ }^{13} \mathrm{C}$ NMR $(100 \mathrm{MHz}$, DMSO, $\delta): 166.22,155.83,143.09,140.99,139.33,130.82,130.70$, 130.50, 129.11, 122.11, 52.89, 14.56. HRMS (ESI) calcd for $\mathrm{C}_{21} \mathrm{H}_{21} \mathrm{BF}_{2} \mathrm{~N}_{2} \mathrm{O}_{2}$ 382.1562, found 382.1570.

Synthesis of 3a-3c. Compound $1(45.9 \mathrm{mg}, 0.12 \mathrm{mmol})$ and (29.7 $\mathrm{mg}, 0.1 \mathrm{mmol}$ ) 2 were dissolved in $10 \mathrm{~mL}$ benzene, $0.12 \mathrm{~mL}$ piperidine and $0.12 \mathrm{~mL}$ acetic acid, and this solution 
was then injected with a syringe. The resulting orange red mixture was stirred with reflux condensation under $90{ }^{\circ} \mathrm{C}$ in the dark. After $8 \mathrm{~h}$, the reaction stopped when the concentration of raw material and product stayed unchanged. The product was washed with water and extracted with dichloromethane. The liquid extracted was dried over anhydrous sodium sulfate. Dichloromethane was removed to obtain the crude product. The crude product was further purified by column chromatography (silica gel) using $\mathrm{CH}_{2} \mathrm{Cl}_{2}$ / hexane $=10 / 1$ as eluent and then, it was recrystallized in $\mathrm{CH}_{2} \mathrm{Cl}_{2}$ /hexane to obtain the target product.

3a. $13 \%$ yield. ${ }^{1} \mathrm{H}$ NMR $\left(400 \mathrm{MHz}, \mathrm{CDCl}_{3}, \delta\right): 8.18(\mathrm{~d}, 2 \mathrm{H}, J=$ 8.4 Hz, Ar-H); 7.72-7.69 (m, 1H, Ar-H); 7.57-7.52 (m, 3H, Ar$\mathrm{H}) ; 7.44(\mathrm{t}, 4 \mathrm{H}, J=8.6 \mathrm{~Hz}, \mathrm{Ar}-\mathrm{H}) ; 7.14-7.12(\mathrm{~m}, 4 \mathrm{H}, \mathrm{Ar}-\mathrm{H})$; 7.07-7.06 (m, 2H, Ar-H); $7.02(\mathrm{~d}, 2 \mathrm{H}, J=8.8 \mathrm{~Hz}, \mathrm{Ar}-\mathrm{H}) ; 6.66$ $(\mathrm{s}, 1 \mathrm{H}$, pyrrole-H); $5.99(\mathrm{~s}, 1 \mathrm{H}$, pyrrole-H); $3.98(\mathrm{~s}, 3 \mathrm{H}$, $\left.-\mathrm{COOCH}_{3}\right) ; 2.58\left(\mathrm{~s}, 3 \mathrm{H}\right.$, pyrrole- $\left.\mathrm{CH}_{3}\right) ; 1.41$ (s, 3H, pyrrole$\left.\mathrm{CH}_{3}\right) ; 1.37$ (s, 3H, pyrrole- $\left.\mathrm{CH}_{3}\right) .{ }^{13} \mathrm{C} \mathrm{NMR} \mathrm{(101} \mathrm{MHz,} \mathrm{CDCl}_{3}$, $\delta): 167.73,154.85,153.89,148.77,147.09,140.08,136.51$, 132.44, 132.36, 132.30, 131.97, 130.89, 130.86, 130.27, 128.82, 128.78, 128.70, 128.62, 125.03, 123.62, 122.39, 121.22, 117.86, 114.73, 52.37, 14.05, 13.72, 10.95. HRMS (ESI) calcd for $\mathrm{C}_{40} \mathrm{H}_{34} \mathrm{BF}_{2} \mathrm{~N}_{3} \mathrm{O}_{2}$ 637.2618, found 637.2612.

3b. $17 \%$ yield. ${ }^{1} \mathrm{H}$ NMR $\left(400 \mathrm{MHz}, \mathrm{CDCl}_{3}, \delta\right): 8.16(\mathrm{~d}, 2 \mathrm{H}, J=$ $8.4 \mathrm{~Hz}, \mathrm{Ar}-\mathrm{H})$; $7.52-7.39(\mathrm{~m}, 11 \mathrm{H}, \mathrm{Ar}-\mathrm{H}) ; 7.12(\mathrm{~d}, 1 \mathrm{H}, J=$ $\left.15.6 \mathrm{~Hz},-\mathrm{CH}=\mathrm{CH}_{\text {Trans }}{ }^{-}\right) ; 6.85\left(\mathrm{~s}, 2 \mathrm{H},-\mathrm{CH}=\mathrm{CH}_{\text {syn }}{ }^{-}\right) ; 6.55(\mathrm{~s}$, $1 \mathrm{H}$, pyrrole-H); 6.28 (d, $2 \mathrm{H}, J=8.4 \mathrm{~Hz}, \mathrm{Ar}-\mathrm{H}) ; 5.95(\mathrm{~s}, 1 \mathrm{H}$, pyrrole-H); 3.97 (s, 3H, $\left.-\mathrm{COOCH}_{3}\right) ; 2.54\left(\mathrm{~s}, 3 \mathrm{H}\right.$, pyrrole- $\left.\mathrm{CH}_{3}\right)$; $1.37\left(\mathrm{~s}, 3 \mathrm{H}\right.$, pyrrole- $\left.\mathrm{CH}_{3}\right) ; 1.34\left(\mathrm{~s}, 3 \mathrm{H}\right.$, pyrrole- $\left.\mathrm{CH}_{3}\right) .{ }^{13} \mathrm{C} \mathrm{NMR}$ (101 $\mathrm{MHz} \mathrm{CDCl}_{3}, \delta$ ): 167.73, 149.95, 142.42, 140.26, 137.62, 137.49, 136.08, 132.44, 132.31, 130.90, 130.86, 130.62, 130.50, $130.41,130.20,129.94,129.79,128.83,128.79,128.60,127.36$, 126.69, 120.74, 117.90, 115.04, 112.17, 52.35, 19.16, 14.05, 10.96. HRMS (ESI) calcd for $\mathrm{C}_{42} \mathrm{H}_{34} \mathrm{BF}_{2} \mathrm{~N}_{3} \mathrm{O}_{2} 661.2615$, found 661.2606.

3c. $16 \%$ yield. ${ }^{1} \mathrm{H}$ NMR $\left(400 \mathrm{MHz}, \mathrm{CDCl}_{3}, \delta\right): 8.17(\mathrm{~d}, 2 \mathrm{H}, J=$ $8.4 \mathrm{~Hz}, \mathrm{Ar}-\mathrm{H})$; $7.72-7.69(\mathrm{~m}, 11 \mathrm{H}, \mathrm{Ar}-\mathrm{H}) ; 7.54-7.52(\mathrm{~m}, 11 \mathrm{H}$, $\mathrm{Ar}-\mathrm{H}) ; 7.43-7.36$ (m, 7H, Ar-H); 7.29-7.15 (m, 5H, Ar-H); 7.17 $\left(\mathrm{d}, 1 \mathrm{H}, J=16 \mathrm{~Hz},-\mathrm{CH}=\mathrm{CH}_{\text {Trans }}{ }^{-}\right) ; 6.60-6.57$ (m, 3H, pyrrole$\mathrm{H}$ and $\mathrm{Ar}-\mathrm{H}) ; 5.96$ (s, $1 \mathrm{H}$, pyrrole- $\mathrm{H}) ; 3.97$ (s, 3H, $\left.-\mathrm{COOCH}_{3}\right)$; $3.00\left(\mathrm{~s}, 4 \mathrm{H},-\mathrm{CH}_{2} \mathrm{CH}_{2}-\right) ; 2.56\left(\mathrm{~s}, 3 \mathrm{H}\right.$, pyrrole- $\left.\mathrm{CH}_{3}\right) ; 1.39(\mathrm{~s}, 3 \mathrm{H}$, pyrrole- $\left.\mathrm{CH}_{3}\right) ; 1.35\left(\mathrm{~s}, 3 \mathrm{H}\right.$, pyrrole- $\left.\mathrm{CH}_{3}\right) .{ }^{13} \mathrm{C} \mathrm{NMR}(101 \mathrm{MHz}$, $\left.\mathrm{CDCl}_{3}, \delta\right): 167.89,150.11,142.58,140.42,137.78,136.24$, 132.60, 131.06, 131.02, 130.78, 130.66, 130.57, 130.36, 130.10, 129.95, 128.99, 128.95, 128.76, 127.52, 126.85, 120.90, 118.06, 115.20, 112.33, 52.51, 23.90, 23.14, 19.32, 14.21, 11.12. HRMS (APCI) calcd for $\mathrm{C}_{42} \mathrm{H}_{36} \mathrm{BF}_{2} \mathrm{~N}_{3} \mathrm{O}_{2} 663.2290$, found 663.2298.

\subsection{Preparation of HFBI-RGD/BODIPY solution}

3a-3c were dissolved in dichloromethane to obtain a certain concentration. Phosphate buffer $(\mathrm{pH}$ 7.4) was used to prepare five concentrations of HFBI-RGD solution (50, 100, 150, 200, 250 $\left.\mu \mathrm{g} \mathrm{mL}^{-1}\right)$. Subsequently, $30 \mu \mathrm{L}$ BODIPY-dichloromethane solution was added to five concentrations of HFBI-RGD $(200 \mu \mathrm{L})$. The layered solutions were self-assembled by ultrasonic agitation for $1 \mathrm{~h}$ below $25{ }^{\circ} \mathrm{C}$. The upper transparent solution was separated for further tests.

\subsection{General biology experiments}

Cell culture. U-87 cells (high $\alpha_{\mathrm{v}} \beta_{3}$ integrin expression) were cultured in DMEM supplemented with $10 \%$ fetal bovine serum and $1 \%$ penicillin/streptomycin. The cells were cultured at $37^{\circ} \mathrm{C}$ in a humidified atmosphere containing $5 \% \mathrm{CO}_{2}$.

Cytotoxicity study. The cytotoxicity of HFBI-RGD/BODIPY fluorescent probe was evaluated by the MTT assay. The U-87 cells were seeded on 96-well plates at a density of $1 \times 10^{5}$ cells per well in DMEM medium overnight for adherence. Then, the cells were treated with different doses of HFBI-RGD/BODIPY $(0 \mu \mathrm{M}, 0.1 \mu \mathrm{M}, 1 \mu \mathrm{M}, 3 \mu \mathrm{M}, 5 \mu \mathrm{M}, 10 \mu \mathrm{M}, 20 \mu \mathrm{M}, 60 \mu \mathrm{M}, 100 \mu \mathrm{M}$, $200 \mu \mathrm{M}$ ) in DMEM supplemented with $10 \%$ fetal bovine serum and $1 \%$ penicillin/streptomycin for further culture of $48 \mathrm{~h}$ at $37{ }^{\circ} \mathrm{C}$ under $5 \% \mathrm{CO}_{2}$. After $48 \mathrm{~h}$ incubation, DMEM was abandoned, and $10 \mu \mathrm{L}$ MTT ( $5 \mathrm{mg} \mathrm{m}^{-1} \mathrm{~L}^{-1}$ ) was added to each well subsequently for $4 \mathrm{~h}$. At last, the formazan crystals in the viable cells were dissolved in $100 \mu \mathrm{L}$ DMSO, and the absorbance at $490 \mathrm{~nm}$ was determined with a microplate reader. The untreated cells were regarded as the $100 \%$ cell viability control, and the treated cell viability (\%) was calculated in line with the following formula: ${ }^{40}$

$$
V \%=\frac{A_{\text {experimental }}}{A_{\text {control }}} \times 100 \%
$$

Here, $V \%$ is the percent of cell viability, $A_{\text {experimental }}$ is the absorbance of the treated cells, and $A_{\text {control }}$ is the absorbance of the untreated cells.

Confocal microscopy. The U-87 cells were seeded onto the 48-well glass slides and cultured in DMEM medium supplemented with $10 \%$ fetal bovine serum and $1 \%$ penicillin/ streptomycin at $37{ }^{\circ} \mathrm{C}$ under $5 \% \mathrm{CO}_{2}$ overnight for attachment. Subsequently, the cells were washed twice with phosphate buffer ( $\mathrm{pH}$ 7.4) and treated with HFBI-RGD/BODIPY or HFBI/BODIPY fluorescent probe in DMEM medium at the concentration $5 \mu \mathrm{M}$. After $4 \mathrm{~h}$ incubation, the cell supernatant was discarded. Then, $4 \%$ formaldehyde solution was added for 5 min to fix the cells, and DAPI solution was added for $10 \mathrm{~min}$ to stain the nucleus. In all cases, the cells were washed with PBS prior to any process to remove the remnant compound from the previous step. Finally, the cells were washed twice and transferred from the cellular slides onto the microscope slides after which they were sealed with a fluorescence quenching sealant. All fluorescence images were taken by a $40 \times$ objective lens. Blue channel $405 \mathrm{~nm}$ was used to visualize the cell nucleus, and red channel $560 \mathrm{~nm}$ was used to excite HFBI-RGD/BODIPY fluorescent probe.

The experiments in vivo. The animal studies complied with the China Animal Protection Law. These experiments were done under the regulations set out for Tianjin University Animal Experiments, and they were approved by the animal ethics committee. Female nude mice (six weeks old) were injected with $100 \mu \mathrm{L}\left(3.5 \times 10^{6}\right.$ cells per $\left.\mathrm{mL}\right)$ glioma cells into the left forelimb to generate the xenograft tumor model. After the mice were 
raised for approximately 2-3 weeks, the HFBI-RGD/BODIPY or HFBI/BODIPY fluorescent probe $(5 \mu \mathrm{M}, 200 \mu \mathrm{L})$ was injected via the tail vein. The mice were anesthetized with isoflurane, and the in vivo images were captured at different points of time. All images were determined with a Cri Maestro In vivo imaging system (Cri, Woburn, MA), with the excitation wavelength of $605 \mathrm{~nm}$ and emission wavelengths ranging from $615 \mathrm{~nm}$ to $800 \mathrm{~nm}$.

The experiments ex vivo. To eliminate the interference from background, ex vivo imaging procedures were carried out. At different time points ( $24 \mathrm{~h}, 48 \mathrm{~h}, 72 \mathrm{~h}$ ), the mice were dissected. The tumor and main organs (heart, liver, spleen, lung, kidneys) were harvested for the ex vivo imaging. The images were taken with the same instrument under the same conditions as those of the in vivo imaging.

\section{Conflicts of interest}

There are no conflicts to declare.

\section{Acknowledgements}

S. X. Meng acknowledges the support of the National Natural Science Foundation of China (No. 21676187, No. 21476162), and China International Science and Technology Project (No. 2012DFG41980, 2016YFE0114900), National Key R\&D Program of China (21761132007). Z. F. Wang acknowledges the support of the National Natural Science Foundation of China (No. 81601593). We also appreciate the favor of Xiaoyan Zhang and Professor Ding from Nankai University and thank Bowei Lu and others for offering help.

\section{Notes and references}

1 S. Osati, H. Ali, F. Marques, M. Paquette, S. Beaudoin, B. Guerin, J. V. Leyton and J. E. van Lier, Bioorg. Med. Chem. Lett., 2017, 27, 443-446.

2 Y. Hiruta, H. Koiso, H. Ozawa, H. Sato, K. Hamada, S. Yabushita, D. Citterio and K. Suzuki, Org. Lett., 2015, 17, 3022-3025.

3 M. Mao, Q.-S. Li, X.-L. Zhang, G.-H. Wu, C.-G. Dai, Y. Ding, S.-Y. Dai and Q.-H. Song, Dyes Pigm., 2017, 141, 148-160.

4 Y. Ooyama, M. Kanda, T. EnoKi, Y. Adachi and J. Ohshita, RSC Adv., 2017, 7, 13072-13081.

5 G. Durán-Sampedro, N. Epelde-Elezcano, V. MartínezMartínez, I. Esnal, J. Bañuelos, I. García-Moreno, A. R. Agarrabeitia, S. de la Moya, A. Tabero, A. LazaroCarrillo, A. Villanueva, M. J. Ortiz and I. López-Arbeloa, Dyes Pigm., 2017, 142, 77-87.

6 B. Kim, B. Sui, X. Yue, S. Tang, M. G. Tichy and K. D. Belfield, Eur. J. Org. Chem., 2017, 25-28.

7 L. Yuan, W. Lin, K. Zheng, L. He and W. Huang, Chem. Soc. Rev., 2013, 42, 622-661.

8 J. Xu, L. Zhu, Q. Wang, L. Zeng, X. Hu, B. Fu and Z. Sun, Tetrahedron, 2014, 70, 5800-5805.

9 E. Y. Schmidt, N. V. Zorina, M. Y. Dvorko, N. I. Protsuk, K. V. Belyaeva, G. Clavier, R. Meallet-Renault, T. T. Vu,
A. I. Mikhaleva and B. A. Trofimov, Chemistry, 2011, 17, 3069-3073.

10 R. Ziessel, S. Rihn and A. Harriman, Chemistry, 2010, 16, 11942-11953.

11 J. Bartelmess, M. Baldrighi, V. Nardone, E. Parisini, D. Buck, L. Echegoyen and S. Giordani, Chem.-Eur. J., 2015, 21, 97279732.

12 S. Liu, Z. Shi, W. Xu, H. Yang, N. Xi, X. Liu, Q. Zhao and W. Huang, Dyes Pigm., 2014, 103, 145-153.

13 B. Brizet, C. Bernhard, Y. Volkova, Y. Rousselin, P. D. Harvey, C. Goze and F. Denat, Org. Biomol. Chem., 2013, 11, 77297737.

14 H. Manzano, I. Esnal, T. Marqués-Matesanz, J. Bañuelos, I. López-Arbeloa, M. J. Ortiz, L. Cerdán, A. Costela, I. García-Moreno and J. L. Chiara, Adv. Funct. Mater., 2016, 26, 2756-2769.

15 X.-D. Jiang, Y. Fu, T. Zhang and W. Zhao, Tetrahedron Lett., 2012, 53, 5703-5706.

16 M. Kamiya and K. Johnsson, Anal. Chem., 2010, 82, 64726479.

17 J. Zhang, X. Bao, J. Zhou, F. Peng, H. Ren, X. Dong and W. Zhao, Biosens. Bioelectron., 2016, 85, 164-170.

18 N. Shivran, M. Tyagi, S. Mula, P. Gupta, B. Saha, B. S. Patro and S. Chattopadhyay, Eur. J. Med. Chem., 2016, 122, 352365.

19 H. Lee, W. Akers, K. Bhushan, S. Bloch, G. Sudlow, R. Tang and S. Achilefu, Bioconjugate Chem., 2011, 22, 777-784.

20 K. Wang, Y. Xiao, Y. Wang, Y. Feng, C. Chen, J. Zhang, Q. Zhang, S. Meng, Z. Wang and H. Yang, Sci. Rep., 2016, 6, 23061.

21 M. Lienemann, J.-A. Gandier, J. J. Joensuu, A. Iwanaga, Y. Takatsuji, T. Haruyama, E. Master, M. Tenkanen and M. B. Linder, Appl. Environ. Microbiol., 2013, 79, 5533-5538.

22 A. Paananen, E. Vuorimaa, M. Torkkeli, M. Penttila, M. Kauranen, O. Ikkala, H. Lemmetyinen, R. Serimaa and M. B. Linder, Biochemistry, 2003, 42, 5253-5258.

23 J. H. A. Hakanpää, G. Z. R. Szilvay, H. Kaljunen, M. Maksimainen, M. Linder and J. Rouvinen, Protein Sci., 2006, 15, 2129-2140.

24 A. Magarkar, N. Mele, N. Abdel-Rahman, S. Butcher, M. Torkkeli, R. Serimaa, A. Paananen, M. Linder and A. Bunker, PLoS Comput. Biol., 2014, 10, e1003745.

25 M. B. Linder, G. z. R. Szilvay, T. N. Setälä and M. E. Penttilä, FEMS Microbiol. Rev., 2005, 29, 877-896.

26 H. J. Hektor and K. Scholtmeijer, Curr. Opin. Biotechnol., 2005, 16, 434-439.

27 H. A. B. Wosten and K. Scholtmeijer, Appl. Microbiol. Biotechnol., 2015, 99, 1587-1597.

28 M. Baruah, W. Qin, C. Flors, J. Hofkens, R. A. L. Vallée, D. Beljonne, M. Van der Auweraer, W. M. De Borggraeve and N. Boens, J. Phys. Chem. A, 2006, 110, 5998-6009.

29 Z. Q. Zhao, Y. Yang, W. Fang and S. Liu, Nucl. Med. Biol., 2016, 43, 661-669.

30 W. Xiao, Y. Wang, E. Y. Lau, J. Luo, N. Yao, C. Shi, L. Meza, H. Tseng, Y. Maeda, P. Kumaresan, R. Liu, F. C. Lightstone, Y. Takada and K. S. Lam, Mol. Cancer Ther., 2010, 9, 27142723. 
31 Q. Zhang, X. Dong, K. Wang, T. Zhu, F. Sun, S. Meng and Y. Feng, Chin. Chem. Lett., 2017, 28, 777-781.

32 C. Wang, J. Li, Z. Ning, D. Zhao and Q. Zhang, Dyes Pigm., 2012, 94, 40-48.

33 K. Do, D. Kim, N. Cho, S. Paek, K. Song and J. Ko, Org. Lett., 2012, 14, 222-225.

34 L. Gai, H. Lu, B. Zou, et al., RSC Adv., 2012, 2, 8840-8846.

35 Z. Li, Y. Chen, X. Lv, et al., New J. Chem., 2013, 37, 3755-3761.

36 R. Gresser, M. Hummert, H. Hartmann, K. Leo and M. Riede, Chemistry, 2011, 17, 2939-2947.
37 X. Cao, L. Meng, Z. Li, Y. Mao, H. Lan, L. Chen, Y. Fan and T. Yi, Langmuir, 2014, 30, 11753-11760.

38 B. Dhokale, T. Jadhav, S. M. Mobin and R. Misra, Dalton Trans., 2015, 44, 15803-15812.

39 J. Zhang, F. Lu, S. Qi, Y. Zhao, K. Wang, B. Zhang and Y. Feng, Dyes Pigm., 2016, 128, 296-303.

40 H. He, D.-W. Li, L.-Y. Yang, L. Fu, X.-J. Zhu, W.-K. Wong, F.-L. Jiang and Y. Liu, Sci. Rep., 2015, 5, 13543. 